\title{
On some parameters in the space of regulated functions and their applications
}

\section{Kinga Cichoń, MieczysŁaw Cichoń and Mohamed M. A. Metwali}

\begin{abstract}
.
In this paper, we study a class of discontinuous functions being a space of solutions for some differential and integral equations. We investigate functions having finite one-sided limits, i.e. regulated functions. In the space of such functions, we introduce some new concepts like a modulus of equi-regularity or a measure of noncompactness, allowing us to unify the proofs for the results about existence for both continuous and discontinuous solutions. An example of applications for quadratic integral equations, essentially improving earlier ones, completes the paper.
\end{abstract}

Acknowledgements. We are grateful to the referees for their helpful comments and constructive suggestions.

\section{REFERENCES}

[1] Agarwal, R. P. and Samet, B., An existence result for a class of nonlinear integral equations of fractional orders, Nonlinear Anal. Model. Control, 21 (2016), 716-729

[2] Akhmerov, R. R., Kamenskiı̌, M. I., Potapov, A. S., Rodkina, A. E. M. and Sadovskŭ, B. N., Measures of Noncompactness and Condensing Operators, Birkhäuser, Basel, 1992

[3] Appell, J. and Zabreiko, P. P., Nonlinear Superposition Operators, Cambridge University Press, Cambridge, 1990

[4] Aziz, W., Guerrero, J. A. and Merentes, N., On nonlinear integral equations in the space $\Phi B V(I)$, J. Fixed Point Theory Appl., 18 (2016), 351-366

[5] Aziz, W., Merentes, N. and Sánchez, J. L., A note on the composition of regular functions, Z. Anal. Anwend, 33 (2014), 119-123

[6] Banaś, J., On measures of noncompactness in Banach spaces, Comment. Math. Univ. Carolin., 21 (1980), 131-143

[7] Banaś, J., Some properties of Urysohn-Stieltjes integral operators, Int. J. Math. Math. Sci., 21, (1998), 79-88

[8] Banaś, J. and Goebel, K., Measures of Noncompactness in Banach Spaces, Lecture Notes in Math., 60, Dekker, New York - Basel, 1980

[9] Banaś, J., Rocha Martin, J. and Sadarangani, K., On solutions of a quadratic integral equation of Hammerstein type, Math. Comput. Modelling, 43 (2006), 97-104

[10] Banaś, J., Rodriguez, J. R. and Sadarangani, K., On a class of Urysohn-Stieltjes quadratic integral equations and their applications, J. Comput. Appl. Math., 113 (2000), 35-50

[11] Banaś, J. and Mursaleen, M., Sequence Spaces and Measures of Noncompactness with Applications to Differential and Integral Equations, Springer, Berlin, 2014

[12] Banaś, J. and Zając, T., A new approach to the theory of functional integral equations of fractional order, J. Math. Anal. Appl., 375 (2011), 375-387

[13] Berberian, S., The character space of the algebra of regulated functions, Pacific J. Math., 74 (1978), 15-36

[14] Billingsley, O., Convergence of Probability Measures, John Wiley, New York, 1968

[15] Brokate, M. and Krejčí, P., Duality in the space of regulated functions and the play operator, Math. Z., 245 (2003), $667-688$

Received: 27.06.2017; In revised form: 15.01.2018; Accepted: 22.01.2018

2010 Mathematics Subject Classification. 26A45, 26A15, 47H08, 45G10.

Key words and phrases. regulated function, discontinuous function, quadratic integral equation, modulus of continuity, measure of noncompactness.

Corresponding author: Mieczysław Cichoń; mcichon@amu.edu.pl 
[16] Cao, Y. and Sun, J., Measures of noncompactness in spaces of regulated functions with application to semilinear measure driven equations, Bound. Value Probl., (2016), No. 38, 17 pp.

[17] Cichon, M. and Metwali, M., On quadratic integral equations in Orlicz spaces, J. Math. Anal. Appl., 387 (2012), $419-432$

[18] Fernandes, L. A. O. and Arbach, R., Regulated functions with values in the Banach algebra of quaternions, in: Proceedings of the World Congress on Engineering, Vol.1, London, 2011

[19] Fraňková, D., Regulated functions, Math. Bohem., 116 (1991), 20-59

[20] Goffman, C., Moran, G. and Waterman, D., The structure of regulated functions, Proc. Amer. Math. Soc., 57 (1976), 61-65

[21] Hönig, C. S., Équations intégrales généralisées et applications (French), [[Generalized integral equations and applications]] Harmonic analysis: study group on translation-invariant Banach spaces, Exp. No. 5, 50 pp., Publ. Math. Orsay 83, 1, Univ. Paris XI, Orsay, 1983

[22] Hönig, C. S., Volterra-Stieltjes Integral Equations, Mathematics Studies, 16, North Holland, Amsterdam, 1975

[23] Michalak, A., On superposition operators in spaces of regular and of bounded variation functions, Z. Anal. Anwend., 35 (2016), 285-308

[24] Mitoma, I., Tightness of probabilities on $C\left([0,1] ; Y^{\prime}\right)$ and $D\left([0,1] ; Y^{\prime}\right)$, Ann. Probab., 11 (1983), 989-999

[25] Nussbaum, R. D., A generalization of the Ascoli theorem and an application to functional differential equations, J. Math. Anal. Appl., 35 (1971), 600-610

[26] Schwabik, S., Linear operators in the space of regulated functions, Math. Bohem., 117 (1992), 79-92

[27] Schwabik, S., On Volterra-Stieltjes integral equations, Časopis Pěst. Mat., 99 (1974), 255-278

[28] Toledano, J. M. A., Dominguez Benavides, T. and Acedo, G. L., Measures of Noncompactness in Metric Fixed Point Theory, Vol. 99, Springer, Berlin, 1997

[29] Tvrdy, M., Linear integral equations in the space of regulated functions, Math. Bohem., 123 (1998), 177-212

[30] Väth, M., Volterra and Integral Equations of Vector Functions, Pure and Applied Mathematics, Vol. 224, Dekker, New York-Basel, 2000

\section{INSTITUTE OF MATHEMATICS}

FACULTY OF ELECTRICAL ENGINEERING

POZNAN UNIVERSITY OF TECHNOLOGY

Piotrowo 3A, 60-965 PozNAŃ, POLAND

E-mail address: kinga.cichon@put.poznan.pl

Faculty of Mathematics AND COMPUter SCience

A. MICKIEWICZ UNIVERSITY

UMULTOWSKA 87

61-614 POZNAŃ, POLAND

E-mail address: mcichon@amu.edu.pl

Department of Mathematics

FACULTY OF SCIENCES

DAMANHOUR UNIVERSITY, EGYPT

E-mail address: $\mathrm{m}$. metwali@yahoo.com 